
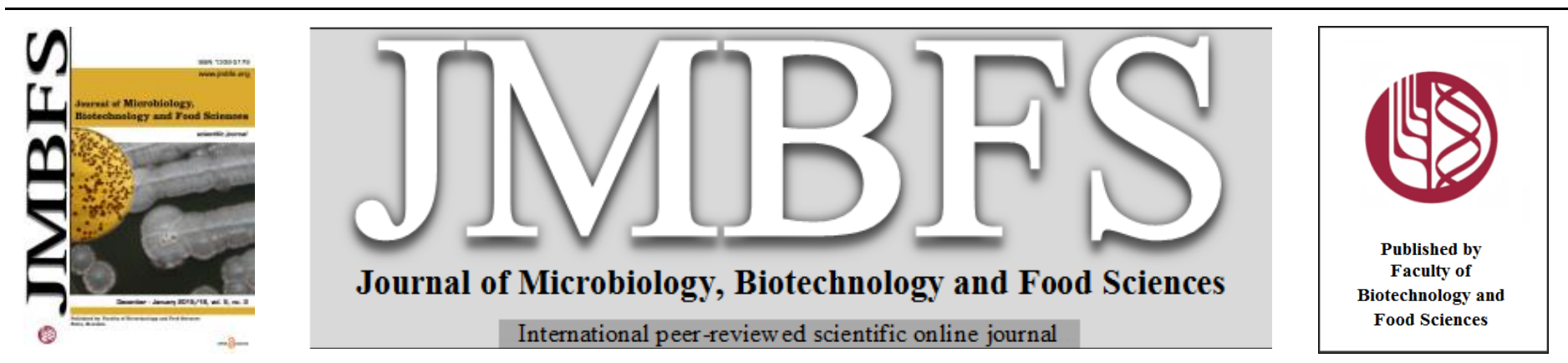

\title{
CHARACTERIZATION OF BACTERIOCIN PRODUCER “LACTOBACILLUS BREVIS UN" AS POTENTIALPROBIOTIC STRAIN
}

\author{
Neha Gautam $*^{1}$ and Nivedita Sharma ${ }^{2}$ \\ Address(es): Neha Gautam, \\ ${ }^{1}$ Department of Biotechnology and Microbiology, St. Bede's College, Navbahar, Shimla (H.P.)-171002, India. \\ ${ }^{2}$ Microbiology Research Laboratory, Department of Basic Sciences, Dr. Y.S. Parmar University of Horticulture and Forestry, Nauni, Solan (H.P.) - 173 230, India. \\ *Corresponding author: neha_mbg@yahoo.com
}

doi: $10.15414 /$ jmbfs.2015/16.5.3.216-220

\section{ARTICLE INFO}

Received 23. 6. 2014

Revised 14. 5. 2015

Accepted 2. 9. 2015

Published 1. 12. 2015

Regular article

OPEN $\partial_{\text {ACCESS }}$

\begin{abstract}
Present study was carried out to classify a bacteriocin producer bacterial isolate, Lactobacillus brevis UN under the category of probiotics. L. brevis $\mathrm{UN}$ isolated from "Dhulliachar" which is a powdered mixture of seeds of Cucurbita pepo and Sesamum indicum consumed by the people of North East region of India as a condiment of food.Isolate was identified by conventional and molecular techniques. Isolated strain was tested for different probiotic attributes. Lactic acid production and auto aggregation capacity of $L$. brevis UN were $1.44 \%$ and $40.54 \%$ respectively. Isolate showed maximum adhesion of $42 \%$ for xylene, survived at pH 1.0 after 180 minutes, exhibited some degree of bile salt tolerance, showed bacteriocin production potential and found sensitive to most of the antibiotics. Overall cumulative probiotic potential for L. brevis UN was $95.83 \%$. L. brevis UN fulfill the criteria of potential probiotic therefore, it can be used by food industries in probiotic preparation.
\end{abstract}

Keywords: Autoaggregation, Bacteriocin, Bile salt, Hydrophobicity, MRS, Probiotic

\section{INTRODUCTION}

Probiotics are live microorganisms that, when administered in adequate amounts, confer a health benefit on the host (FAO, 2002). They are also called "friendly bacteria" or "good bacteria"can be used as complementary/alternative medicine and are not presently considered to be part of conventional medicine (Saikhon and Jairath 2010). In today's world overuse of antibiotics and lesser consumption of traditional fermented food products by human population have disrupted the beneficial microflora of gastrointestinal tract. Due to lack of beneficial bacteria, GI track is prone to the attack of pathogenic organisms which may cause immune dysfunctions such as allergies, asthma, eczema, depression, bipolar disease, ADHD etc. Therefore, probiotics are recommended by doctors and, more frequently by nutritionists, after a course of antibiotics to re-stimulate immune functions (Green, 2010). Ingestion of probiotics improves human immune function. Most commonly used probiotics are species of Lactobacilli and Bifidobacteria. Most probiotic products consist of one or more species of bacteria from one or both of these types.L. brevis is widely seen in nature and has been found in fermented foods of both plant and animal origin as well as in human intestinal flora (Yakabeet al., 2009) and can therefore, be used as a probiotic.

$L$. brevis has been patented several times. Though, several workers have claimed the effectiveness of $L$. brevisas a probiotic but many strains of $L$. brevis are still unrecognized, as different strains of a species exhibit differences in acid and bile resistance, ability to colonize the gastrointestinal (GI) tract, clinical efficacy, and the health benefits they confer. Therefore, in present investigation an effort has been made to place bacteriocin producing new isolate of "Dhulliachar" - $L$. brevis UN into a class of probiotics that could be utilized in dietary supplements.

\section{MATERIAL AND METHODS}

\section{Isolation, screening and identification of lactic acid bacteria}

Lactic acid bacterial strain was isolated from "Dhulliachar"which is being consumed by the people of North East region of India. Isolation was carried out on De Man Ragaosa Sharpe (MRS) agar (Hi-media make) under anaerobic conditions by standard spread plate method (Aneja et al., 2003). Screening of isolates was done on the basis of morphological, physiological, biochemical characteristics and antagonistic potential (Gautam et al., 2014; Barefoot and Klaenhammer 1983). Colour, form, margin, elevation and texture of each isolated strain were noted down. Gram staining, catalase test, oxidase test, citrate utilization test, gas production from glucose, casein hydrolysis, $\mathrm{H}_{2} \mathrm{~S}$ production and sugar fermentation were performed with isolated strains by standard microbiological techniques. Serious food borne pathogens/food spoilage bacteria i.e. Listeria monocytogenes MTCC 839 and Leuconostoc mesenteroides MTCC 107, Enterococcus faecalis MTCC 2729, Lactobacillus plantarum CRI, Bacillus cereus CRI, Clostridium perfringens MTCC 1739, Pectobacterium caratovorum MTCC 1428, Escherichia coli IGMC and Staphylococcus aureus IGMC, Aeromonas hydrophila IGMC were used to study antimicrobial potential of isolated strains. The test strains were procured from Institute of Microbial Technology (IMTECH), Chandigarh, India, Central Research Institute, Kasuali, India and Indira Gandhi Medical College (IGMC), Shimla, India. All these test strains were revived twice for $24 \mathrm{~h}$ at $37^{\circ} \mathrm{C}$ before performing the experiments, as all these indicators were preserved in $40 \%$ glycerol at $-20^{\circ} \mathrm{C}$. The bit disk method (Gautam and Sharma 2009; Kimura, 1998; Sharma et al., 2009) and well diffusion method (Del et al., 2000) were used to study antimicrobial potential of isolated strains. The gram positive, catalase-negative rods having maximum antagonistic activity were selected for further studies. Out of 12 isolates UN was selected. On the basis of $16 \mathrm{~S}$ rRNA gene technique UN identified as Lactobacillus brevis. The sequences so obtained were submitted in National Centre for Biotechnology Information (NCBI) to get an accession numbers. $L$. brevis UN registered under the accession no. JX046150 (Gautam et al., 2014).

\section{Probiotic attributes}

Probiotic potential of L. brevis UN was studied by evaluating various factors viz., bacteriocin producing potential, lactic acid production, autoaggregation capacity, adhesion to solvents, bile salt tolerance and antibiotic sensitivity.

\section{Bacteriocin production}

L. brevis UN (10\%) was inoculated in MRS broth and incubated at $35^{\circ} \mathrm{C}$, at 120 rpm for $30 \mathrm{~h}$ in orbital shaker. The isolate with $1.99 \mathrm{OD}$ was centrifuged at $18,000 \mathrm{rpm}$ for $20 \mathrm{~min}$ at $4^{\circ} \mathrm{C}$. The supernatant was filtered and collected in a sterilized test tube. This collected supernatant was neutralized to $\mathrm{pH} 7.0$ (with sterilized $1 \mathrm{~N} \mathrm{NaOH}$ ) and catalase was added (2 $\mathrm{mg}$ in $20 \mathrm{ml}$ ). Well diffusion method was repeated with this preparation against respective indicators. Further bacteriocin activity in cell free supernatants was determined by activity unit per milliliter (AU/ml). Activity unit per $\mathrm{ml}$ was determined as the inverse of the last 
dilution at which growth inhibition was still detectable following the well diffusion (Gautam et al., 2014; Gautam and Sharma 2009; Kimura, 1998)

\section{Lactic Acid production}

\section{Inoculum preparation}

Twenty four h old active culture of L. brevis UN was inoculated (1\% v/v) into 10 $\%$ sterile reconstituted skimmed milk and incubated at $35{ }^{\circ} \mathrm{C}$ for $72 \mathrm{~h}$. Samples were withdrawn every $24,48,72 \mathrm{~h}$ interval of incubation period. The $\mathrm{pH}$ of cultured reconstituted skimmed milk was measured using $\mathrm{pH}$ meter and acidity was determined by titrating cultured reconstituted skim milk against $0.1 \mathrm{~N}$ $\mathrm{NaOH}$ as given below:

\section{Acidity in terms of lactic acid (Gotcheva et al., 2002; Ranganna, 1997)}

An aliquot of the sample prepared was diluted with recently boiled distilled water. 2-3 drops of $1 \%$ phenolphthalein solution was used as an indicator and titration was done with $0.1 \mathrm{~N} \mathrm{NaOH}$. Titre value was noted and calculations were done as percent anhydrous lactic acid.

Titratable acidity $(\%)=\frac{\begin{array}{c}\text { Titre } \times \text { Normality of alkali x Volume made } \\ \text { up x Equivalent weight }\end{array}}{\begin{array}{c}\text { Volume of sample taken } \times \text { Volume of } \\ \text { aliquot taken } \times 1000\end{array}} \times 100$

\section{Autoaggregation assay(Walker and Gilliland 1993)}

The active bacterial culture $L$. brevis $\mathrm{UN}(25 \mathrm{ml})$ was centrifuged at 10,000 rpm for $10 \mathrm{~min}$ at $4^{0} \mathrm{C}$. Pellets were collected, washed twice in sterile phosphate buffer saline (PBS ,0.1 M phosphate buffer, $0.8 \% \mathrm{NaCl}, \mathrm{pH} 7.2$ ), re-suspended in 25 $\mathrm{ml}$ PBS and mixed by gentle vortexing for $10 \mathrm{~s}$. Absorbance was measured at $\mathrm{OD}_{620}$ and incubated for $1 \mathrm{~h}, 2 \mathrm{~h}$ and $3 \mathrm{~h}$ at $35^{\circ} \mathrm{C}$. Absorbance of upper suspension was measured after each interval. Autoaggregation $\%$ was measured as : A0 $(\mathrm{At} / \mathrm{A} 0) \times 100$, where At represents the absorbance at time $\mathrm{t}=1 \mathrm{~h}$ and $\mathrm{A} 0$ the absorbance at $\mathrm{t}=0 \mathrm{~h}$

\section{Bacterial adhesion to solvents(Walker and Gilliland 1993)}

Twenty four h old L. brevis $\mathrm{UN}(25 \mathrm{ml})$ were centrifuged at $10,000 \mathrm{rpm}$ for 10 min at $4^{0} \mathrm{C}$ and pellets were washed twice in sterile phosphate buffer saline (PBS ,0.1 M Phosphate buffer, $0.8 \% \mathrm{NaCl}, \mathrm{pH} 7.2$ ), resuspended in $0.1 \mathrm{M} \mathrm{KNO}$ ( pH6.2).Initial absorbance was measured at $\mathrm{OD}_{620} \mathrm{~nm}$ as $\mathrm{A} 0.3 \mathrm{ml}$ of cell suspension was taken in three test tubes and solvents viz. xylene, chloroform, ethyl acetate $(1.0 \mathrm{ml})$ was added separately in each test tube. After pre-incubation for $10 \mathrm{~min}$ at room temperature, two phases were mixed by gentle vortexing for 2 min followed by further incubation for $20 \mathrm{~min}$ at room temperature. The aqueous phase so formed after 20 min was measured at $\mathrm{OD}_{620}$ as At. The percent of bacterial adhesion to solvent was calculated as A0- $(\mathrm{At} / \mathrm{A} 0) \times 100$. where At represents the absorbance at time $\mathrm{t}=1 \mathrm{~h}$ and $\mathrm{A} 0$ the absorbance at $\mathrm{t}=0 \mathrm{~h}$.

\section{Acid tolerance (Tambekar and Bhutada 2010)}

Twenty four h old active culture of L. brevis UN was centrifuged at 10,000 rpm for $10 \mathrm{~min}$ at $4^{0} \mathrm{Cand}$ pellets so collected were washed twice in sterile phosphate buffer saline (PBS, 0.1 M Phosphate buffer, $0.8 \% \mathrm{NaCl}, \mathrm{pH} 7.2$ ) and resuspended in PBS. Suspended bacterial cells in PBS were further diluted $1 / 100$ in PBS at $\mathrm{pH} 1.0,2.0$ and 3.0 and incubated for 1,2 and $3 \mathrm{~h}$ at $37^{\circ} \mathrm{C}$. Counts of surviving bacterial colonies were determined after plating the isolate on MRS agar with appropriate $\mathrm{pH}$ and incubating them anaerobically at $37{ }^{\circ} \mathrm{C}$ overnight. Control samples without acidification were also prepared and similarly handled.

\section{Bile salt tolerance (Lindgren and Dobrogosz 1990)}

L.brevis UN was evaluated for its ability to grow in the presence of bile salt (Himedia make). $24 \mathrm{~h}$ old L.brevis UN (1\% v/v) was inoculated into MRS broth supplemented with $0.3 \%$ bile salt and incubated at $37{ }^{\circ} \mathrm{C}$ for different time period i.e. $0 \mathrm{~h}$ to $72 \mathrm{~h}$. Absorbance was measured at $620 \mathrm{~nm}$ during the incubation an increase or decrease in absorbance was used to compare growth of cultures in presence of bile salt

\section{Antibiotic resistance}

Twenty four h old active culture of $L$. brevis $\mathrm{UN}$ was seeded on MRS agar plates using swab. Antibiotic-impregnated discs (Hi-media, India) (Table 1) were placed on seeded plates and the zone of growth inhibition was measured after $24 \mathrm{~h}$ of incubation at $37^{\circ} \mathrm{C}$ to detect its sensitivity for them (Halamiet al., 1999)

$\underline{\text { Table } 1 \text { Antibiotics used and their concentrations }}$

\begin{tabular}{lcc}
\hline S. No. & Antibiotic used & Concentration $(\boldsymbol{\mu g})$ \\
\hline 1 & Ampicillin & 10 \\
\hline 2 & Gentamicin & 10 \\
\hline 3 & Nalidixic & 30 \\
\hline 4 & Chlorophenicol & 30 \\
\hline 5 & Ceflazidine & 30 \\
\hline 6 & Cefotaxime & 30 \\
\hline 7 & Ciprofloxacin & 5 \\
\hline 8 & Oloxacin & 5 \\
\hline 9 & Tetracycline & 30 \\
\hline 10 & Amoxyclov & 30 \\
\hline 11 & Co-trimoxazole & 25 \\
\hline 12 & Cefuroxime & 30 \\
\hline 13 & Vancomycin & 30 \\
\hline 14 & Methicillin & 30 \\
\hline & &
\end{tabular}

Cumulative probiotic potential (Bhaktaet al., 2010)

The cumulative probiotic potential of L. brevis UN was calculated by using standard score card.

\section{RESULTS AND DISCUSSION}

\section{Antagonistic potential of $L$. brevis UN}

Inhibitory activity of $L$. brevis UN was tested against selected food borne/spoilage causing bacteria viz. i.e. Listeria monocytogenes MTCC 839 and Leuconostocmesenteroides MTCC 107, Enterococcus faecalis MTCC 2729, Lactobacillus plantarum CRI, Bacillus cereus CRI, Clostridium perfringens MTCC 1739, Pectobacteriumcaratovorum MTCC 1428, Escherichia coli IGMC Staphylococcus aureus IGMC and Aeromonashydrophila IGMC. L. brevis UN exhibited $60 \%$ inhibition against test pathogens (Gautam et al., 2014). The data on inhibitory spectrum by bit/disc and well diffusion method is shown in Table 2.

Table 2 Antagonistic spectrum of L. brevisUN by Bit disc/well diffusion method in terms of zone size

\begin{tabular}{|c|c|c|c|c|c|c|c|c|c|c|c|}
\hline Methods & $\begin{array}{c}L . \\
\text { monocytogenes }\end{array}$ & $\begin{array}{c}L . \\
\text { mesenteroides }\end{array}$ & $\begin{array}{c}S . \\
\text { aureus }\end{array}$ & $\begin{array}{c}\text { L. } \\
\text { plantarum }\end{array}$ & $\begin{array}{c}\text { B. } \\
\text { cereus }\end{array}$ & $\begin{array}{c}C . \\
\text { perfringens }\end{array}$ & $\begin{array}{c}A . \\
\text { hydrophila }\end{array}$ & $\begin{array}{c}E . \\
\text { faecalis }\end{array}$ & $\begin{array}{c}E . \\
\text { coli }\end{array}$ & $\begin{array}{c}P . \\
\text { caratovorum }\end{array}$ & $\%$ inhibition \\
\hline Bit disc method & $5 \mathrm{~mm}$ & $3 \mathrm{~mm}$ & $5 \mathrm{~mm}$ & $3 \mathrm{~mm}$ & $10 \mathrm{~mm}$ & $1 \mathrm{~mm}$ & - & - & - & - & 60 \\
\hline $\begin{array}{l}\text { Well diffusion } \\
\text { method }\end{array}$ & $3 \mathrm{~mm}$ & - & $8 \mathrm{~mm}$ & $1 \mathrm{~mm}$ & - & $3 \mathrm{~mm}$ & - & $1 \mathrm{~mm}$ & $1 \mathrm{~mm}$ & - & 60 \\
\hline
\end{tabular}

Antagonistic activity in terms of inhibitory zone.

$$
* \text { Percent Inhibition }(\%)=\frac{\text { No of inhibited indicators }}{\text { Total no. of indicators }} \text { X100 }
$$

\section{Bacteriocin production}

Bacteriocin production was estimated in terms of activity units of culture supernatant. The activity units were found to be $2 \times 10^{3} \mathrm{AU} / \mathrm{ml}$.

\section{Calculation of $\mathrm{AU} / \mathrm{ml}$ for crude bacteriocin of $L$. brevis $\mathrm{UN}$}

$\begin{array}{lll}100 \mu \mathrm{l} & = & 200 \\ 1 \mu \mathrm{l} & = & 200 / 100\end{array}$

$1000 \mu \mathrm{l}=200 / 100 \times 1000=2 \times 10^{3} \mathrm{AU} / \mathrm{ml}$

*Arbitrary unit (reciprocal of highest dilution forming detectable zone of inhibition) expressed in the form of AU. 


\section{Lactic acid production}

Production of lactic acid by LAB is most significant attribute for its use as probiotic strain. Lactic acid is a major end product of fermentation process Maximum lactic acid is produced during stationary phase. Production of lactic acid during growth phase L. brevis UN has been presented in Table 3. The lactic acid production was measured by standard method as described by (Gotcheva $\boldsymbol{e}$ al., 2002). At 0 h, lactic acid production was minimum i.e. $0.27 \%$ and $\mathrm{pH}$ was

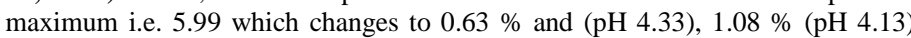
and $1.44 \%(\mathrm{pH} 4.01)$ after 24,48 and $72 \mathrm{~h}$ of growth. Statistically correlation studies revealed that there was a negative relationship between the lactic acid concentration and $\mathrm{pH}$ during the growth phase $(\mathrm{r}=-0.8507$ for $L$. brevis $\mathrm{UN})$ i.e. lactic acid production is minimum when $\mathrm{pH}$ is highest and vice-versa.

Lactic acid bacteria are either homo-fermenters or hetero-fermenters depending upon metabolites they produce. L. brevis $\mathrm{UN}$ is hetero-fermenters as it produce lactic acid, hydrogen peroxide as well as ethanol (Kandler, 1983). Maximum lactic acid is produced during stationary phase. Lactic acid production by LAB's is one of the important criteria for its use as probiotic strain as this acid is a secondary metabolite which often plays an important role in defense mechanism by inhibiting the pathogenic bacteria and thus aids in colonization of LAB. One of the study showed that Lactobacillus salivarius capable of producing high amounts of lactic acid, which can inhibit the growth of $H$. pylori in vitro and it was concluded from the study that higher the level of lactic acid production by Lactobacillus, the more potent will be the effect on reducing $H$. pylori's urease activity (Rayan et al., 2008).

Table 3 Estimation of Lactic acid production by L. brevis $\mathrm{UN}$

\begin{tabular}{lcc}
\hline Time & Lactic acid (\%) & pH \\
\hline $\mathbf{0 ~ h}$ & 0.27 & 5.99 \\
\hline $\mathbf{2 4} \mathbf{~ h}$ & 0.63 & 4.33 \\
\hline $\mathbf{4 8} \mathbf{~ h}$ & 1.08 & 4.13 \\
\hline $\mathbf{7 2} \mathbf{~ h}$ & 1.44 & 4.01 \\
\hline
\end{tabular}

Titre x Normality of Alkali x Volume made up x

Titratable acidity $=$ Equivalent weight

(\%) $\quad=\frac{\text { Volume of sample taken } \mathrm{x} \text { Volume of aliquot taken }}{\mathrm{X}} \mathrm{X}$ x 1000

\section{Autoaggregation on the basis of sedimentation rate}

Table 4 is depicting autoaggregation of L. brevis UN on the basis of sedimentation rate for $2 \mathrm{~h}$. Autoaggregation capacity of bacterial isolate was measured by comparing the initial absorbance at $600 \mathrm{~nm}$ with absorbance of $1^{\text {st }} \mathrm{h}$ and $2^{\text {nd }} \mathrm{h}$. The autoaggregation percentage was measured by A0- (At/A0) $\times 100$ It was noticed that for the $1^{\text {st }} \mathrm{h}$ of incubation autoaggregation $\%$ for L. brevis UN was $27 \%$ and for $2^{\text {nd }} \mathrm{h}$ of incubation it was $40.54 \%$. The autoaggregation ability exhibited by bacteria may contribute on its adhesion property. Such ability of microorganism provide resistance to peristaltic elimination by providing competitive advantage in ecosystem (Ahire $\boldsymbol{e t}$ al., 2011). Above mentioned results showed that $L$. brevis UN exhibited a strong autoaggregating phenotype that is a required character for preparation of probiotic supplements.

Table 4 Autoaggregation* of L. brevis UN

\begin{tabular}{lcc}
\hline Time & OD $_{\mathbf{6 0 0}}$ & $* *$ Autoaggregation (\%) \\
\hline $0 \mathrm{~h}$ & $1.85 \pm 0$ & 27 \\
\hline $1 \mathrm{~h}$ & $1.35 \pm 0.008$ & 40.54 \\
\hline $2 \mathrm{~h}$ & $1.10 \pm 0.009$ & \\
\hline
\end{tabular}

*Autoaggregation interms of sedimentation rate

$-\mathrm{OD}_{600}=$ Mean $( \pm$ Standard Deviation $)$ of results from three separate experiments

**Autoaggregation \% $=\mathrm{A} 0-(\mathrm{At} / \mathrm{A} 0) \times 100$

\section{Bacterial adhesion to solvents}

The microbial adhesion to solvents was used to evaluate the hydrophobic/hydrophilic cell surface properties of $L$. brevis UN. The ability to adhere can give information about the possibility of probiotics to colonize and may modulate the host immune system. Cell hydrophobicity is one of factors that may contribute to adhesion of bacterial cells to host tissues. This property could indicate an advantage and importance for bacterial maintenance in the human gastrointestinal tract (Klayraung et al., 2008). The results in Table 5 indicated that $L$. brevis UN is fully hydrophobic, as it showed $42 \%$ adhesion towards xylene, $22 \%$ towards ethyl acetate while $13.75 \%$ towards chloroform. Bacterial adhesion to xylene, chloroform and ethyl acetate was tested to assess the Lewis acid-base characteristics of the bacterial cell surfaces. L. brevis UN showed stronger affinity for xylene, which is a polar solvent, thus demonstrated hydrophobic cell surface of the strain which is highly desirable probiotic attributes. The three different solvents were tested in this study, Out of these xylene reflected cell surface hydrophobicity because it is a polar solvent whereas chloroform- a monopolar acidic solvent and ethyl acetate-a monopolar basic solvent were regarded as a measure of electron donor and electron acceptor. In literature it has been discussed that the presence of (glycol-) proteinaceous material at the cell surface results in higher hydrophobicity, whereas hydrophilic surfaces are associated with the presence of polysaccharides (Kos et al. 2003). Therefore, it could be said that there is a presence of (glycol-) proteinaceous material on the cell surfaces of L. brevis (Pelletier et al., 1997).

Table 5Adhesion of L. brevis UN to different hydrocarbons

\begin{tabular}{lccc}
\hline S.No. & $\begin{array}{c}\text { Name of } \\
\text { hydrocarbon }\end{array}$ & OD $_{\mathbf{6 0 0}} \boldsymbol{\%}$ & \% Hydrophobicity** \\
\hline 1 & Chloroform & $1.38 \pm 0.45$ & 13.75 \\
\hline 2 & Xylene & $1.12 \pm 0.012$ & 42 \\
\hline 3 & Ethyl acetate & $1.31 \pm 0.016$ & 22 \\
\hline
\end{tabular}

$\checkmark$ OD: Mean ( $₫$ Standard Deviation) of resultsfrom three separate experiments **Hydrophobicity\%:A0- (At /A0)

\section{Acid tolerance}

To resist acidic $\mathrm{pH}$ of gastric juices is an important characteristic of probiotic lactic acid bacteria. Acid tolerance of isolate was studied by suspending bacterial cells in phosphate buffer saline of different $\mathrm{pH} 1.0,2.0$ and 3.0 following incubation for $60 \mathrm{~min}, 120 \mathrm{~min}$ and $180 \mathrm{~min}$. It was observed from the following experiment that cells of L. brevis UN resisted an incubation period of 60 to 180 $\mathrm{min}$ at $\mathrm{pH} 1.0$ to 3.0. Table 6 is depicting \% survival of L. brevis $\mathrm{UN}$ at different $\mathrm{pH}$ for different time interval. Though, L. brevis $\mathrm{UN}$ survived at $\mathrm{pH} 1.0$ after an incubation period of $3 \mathrm{~h}$ but survival was slightly less i.e. $91.87 \%$ at $\mathrm{pH} 1.0$ as compare to $\mathrm{pH} 2.0$ and 3.0 where survival \% was 91.98 and $94.5 \%$ with the same incubation period. In contrast to acidic $\mathrm{pH}$, survival $\%$ was $100 \%$ in control after 180 min of incubation. So it could be said that isolate L. breviscould be possible probiotic candidate bearing acid tolerance properties.

The acid tolerance of $\mathrm{LAB}$ is dependent upon the $\mathrm{pH}$ profile of $\mathrm{H}^{+}$-ATPase and the composition of the cytoplasmic membrane, which is largely influenced by the type of bacteria, type of growth media and growth conditions. In one of the study conducted by Hoque et al., (2010), it was found that a probiotic isolate i.e. Lactobacillus-2 was able to grow at low $\mathrm{pH}$ (2.2).

Table 6 Acid tolerance of L. brevis UN

\begin{tabular}{|c|c|c|c|c|c|}
\hline \multicolumn{6}{|c|}{$\log _{10} \mathrm{cfu} / \mathrm{ml}^{*}$} \\
\hline S.No. & 0 min & $60 \mathrm{~min}$ & $120 \mathrm{~min}$ & $180 \mathrm{~min}$ & $\begin{array}{c}\text { \% survival after } 180 \\
\text { min. }\end{array}$ \\
\hline 1 & $10.21 \pm 0.008$ & $9.80 \pm 0.024$ & $9.80 \pm 0.024$ & $9.38 \pm 0.07$ & 91.87 \\
\hline 2 & $10.23 \pm 0.004$ & $10.15 \pm 0.008$ & $9.91 \pm 0.012$ & $9.41 \pm 0.09$ & 91.98 \\
\hline 3 & $10.20 \pm 0.009$ & $10.21 \pm 0.012$ & $10.18 \pm 0.008$ & $9.64 \pm 0.036$ & 94.50 \\
\hline Control & $10.24+0.008$ & $10.26 \pm 0.0081$ & $10.23 \pm 0.004$ & $10.25 \pm 0.012$ & 100 \\
\hline
\end{tabular}

*Log cfu/ml : Mean ( \pm standard deviation) of results from three separate experiments ) 


\section{Bile salt tolerance}

L. brevis UN was compared for its ability to grow in the presence of bile salt (Himedia make). Twenty four h old, each bacterial culture $(1 \% \mathrm{v} / \mathrm{v})$ was inoculated into MRS broth supplemented with $0.3 \%$ bile salt and incubated at $37{ }^{0} \mathrm{C}$ for different time period i.e. $0 \mathrm{~h}$ to $60 \mathrm{~h}$. Absorbance at $620 \mathrm{~nm}$ and viable count was performed during the incubation period after every $4 \mathrm{~h}$. Increase or decrease in absorbance and viable count was used to compare growth of culture in presence of bile salt. L. brevis UN exhibited some degree of bile tolerance. For L. brevis UN OD and $\log \mathrm{cfu} / \mathrm{ml}$ for bile salt treated cells at $0 \mathrm{~h}$ was 0.084 and 7.81 for control 0.08 and 7.82. It was noticed that after $4^{\text {th }} \mathrm{h}$ of incubation the cells growing in presence of bile salt were multiplying with almost at similar rate as that of control as OD and viable count for cells growing in presence of bile salt was 0.112 and 9.32 , for control 0.12 and 9.34. At $8^{\text {th }}$ h of incubation OD was 0.44 and $\mathrm{cfu} / \mathrm{ml}$ was 9.52 for cells growing in presence of bile salt while for contro OD was 0.55 and $\mathrm{cfu} / \mathrm{ml}$ was 9.62 . After $12^{\text {th }} \mathrm{h}$ of growth the OD for control was found to increase continuously, on $28^{\text {th }} \mathrm{h}$ of growth it became 1.99 with 10.18 $\log \mathrm{cfu} / \mathrm{ml}$. OD of cells growing in presence of bile salt remain lower than control and was almost constant in between the range of 0.44 to 0.48 with 9.53 to 9.56 $\log \mathrm{cfu} / \mathrm{ml}$ upto $48^{\text {th }} \mathrm{h}$ of growth. After $56^{\text {th }} \mathrm{h}$ growth there was a decline in OD of bile salt treated cells was observed as OD came to 0.02 but for control OD was 1.99. Beside the strong acid media in the stomach, the probiotic microorganisms taken orally have to defend against the bile salt in the gastrointestinal tract Hence, the bile salt is considered to be one of the most important properties required for high survival and a consequence for a probiotic activity. The physiological concentration of bile salt in the small intestine is between 0.2 and $0.3 \%$ (Walker and Gillliland, 1993). Due to this fact, higher acid and bile salt tolerant strains of LAB would act as potential probiotics Bhaktaet al., (2010).

\section{Sensitivity to antibiotics of $L$. brevis UN}

L. brevis UN was tested for antibiotic susceptibility / resistivity with antibiotic discs (Hi-media Make). Different antibiotic discs were used viz. ampicillin AMP $(10 \mu \mathrm{g})$, gentamicin GEN $(10 \mu \mathrm{g})$, nalidixic $\mathrm{NA}(30 \mu \mathrm{g})$, chloramphinicol $\mathrm{CH}$ $(30 \mu \mathrm{g})$, ceftazidine CTZ $(30 \mu \mathrm{g})$, cefatoxime CTX $(30 \mu \mathrm{g})$, ciprofloxacin CFX $(5 \mu \mathrm{g})$, oloxacin OLO $(10 \mu \mathrm{g})$ tetracycline TET $(30 \mu \mathrm{g})$, amoxyclov AMX $(30 \mu \mathrm{g})$, co-trimoxazole CO-TRI $(25 \mu \mathrm{g}$, ) cefuroxime CEF $(30 \mu \mathrm{g} \mu \mathrm{g})$, vancomycin VAN $(10 \mu \mathrm{g})$, methiocillin MET $(10 \mu \mathrm{g})$. L. brevis UN showed sensitivity against most tested antibiotics and were found resistant against only few viz. nalidixic $(30 \mu \mathrm{g})$, ciprofloxacin $(5 \mu \mathrm{g})$ and oloxacin as shown in (Table 7). Lactobacilli are usually sensitive to inhibitors of protein synthesis and resistant to glycopeptides(Coppola et al., 2005; Zhou et al., 2005) but in our study L. brevis UN was found sensitive to protein inhibitors viz. ampicillin, chlormphenicol and tetracyclin as well as to glycopeptidesi.e.vancomycin. The antibiotic susceptibility of L. brevis UN make it very crucial for the safety point of view to their use as potential probiotics since bacteria used as probiotic may act as potential reservoirs for antimicrobial resistance genes, which can be transferred to pathogenic bacteria. According to world health organization WHO, 2001 and European Food Safety Authority-EFSA, 2008 bacteria used as probiotics for humans or animals should not carry any transferable antimicrobial resistance genes. Thus the susceptibility of our LAB isolate to the clinically importan antimicrobials is beneficial as it minimizesthe chances of disseminating resistance genes to pathogens both in the food matrix and/or in the gastrointestinal tract.It could, thus, be concluded that L. brevis UN is not reservoirs of transferable resistance genes and can be used to prepare safe probiotic supplements.

Table 7 Antibiotic Sensitivity profile of selected LAB and selected pathogens

\begin{tabular}{|c|c|c|c|c|c|c|c|c|c|c|c|c|c|c|}
\hline Bacterial strains & AMP & GEN & NA & CH & CTZ & CTX & CFX & OLO & TET & AMX & CO-TRI & CEF & VAN & MET \\
\hline L. brevis UN & $\mathbf{S}$ & $\mathbf{S}$ & $\mathbf{S}$ & $\mathbf{S}$ & $\mathbf{S}$ & $\mathbf{S}$ & $\mathbf{R}$ & $\mathbf{R}$ & $\mathbf{S}$ & $\mathbf{S}$ & $\mathbf{S}$ & $\mathbf{S}$ & $\mathrm{S}$ & S \\
\hline
\end{tabular}

\section{Cumulative probiotic score of $L$. brevis UN}

The probiotic potential of bacterial strains is based upon cumulative probiotic score. Cumulative probiotic potential is the sum of score of acid, bile tolerance autoaggregation capability, antibiotic resistance and antibacterial activity. Probiotic potential for the isolate was calculated by following formula:

$$
\text { Probiotic potential }=\frac{\text { Observed score }}{\text { Maximum score }} \times 100
$$

In the present investigation probiotic potential for L. brevis UN was $95.83 \%$ Table 8 .The commercially available probiotic preparationshas probiotic score in a range of 75 to $85 \%$. The present study revealed that L. brevis UN follows the criteria of FAO/WHO (2002). Hence this study affirm the use of L. brevis UN in the development of new pharmaceutical and functional foods for the bettermen of the health of public as these two strains have been proved safe in present study.

$\underline{\text { Table } 8 \text { Calculation of cumulative probiotic effect of } L \text {. brevis UN }}$

\begin{tabular}{lcc}
\hline Probiotic characters & Indication & Score \\
\hline Lactic acid production & $\begin{array}{l}\text { Resistant }=1 \\
\text { Sensitive }=0\end{array}$ & 1 \\
\hline Acidity tolerance & $\begin{array}{l}\text { Resistant }=1 \\
\text { Sensitive }=0\end{array}$ & 1 \\
\hline Autoaggregation capacity & $\begin{array}{l}\text { Positive }=1 \\
\text { Negative }=0\end{array}$ & 1 \\
\hline Bile salt tolerance & $\begin{array}{l}\text { Resistant }=1 \\
\text { Sensitive }=0\end{array}$ & 1 \\
\hline Antagonistic activity & $\begin{array}{c}<3=0.25 \\
=0.50\end{array}$ \\
\hline $\begin{array}{c}3-5 \\
5-20=0.75 \\
20\end{array}$ & 0.75 \\
\hline Antibiotic sensitivity & $\begin{array}{l}\text { Antibiotic sensitive }=1 \\
\text { Antibiotic resistant }=0\end{array}$ & 1 \\
\hline Total & \\
\hline
\end{tabular}

$$
* * \text { Probiotic potential }=\frac{\text { Observed score }}{\text { Maximum score }} \times 100
$$

Probiotic potential $=95.83 \%$

\section{CONCLUSION}

In the present study bacteriocin producer $L$. brevis UN was isolated from rarely reported condiment "Dhulliachar. The strain was characterized for its probiotic potential and it showed all the desirable properties of a good probiotic strain viz., bacteriocin production, acid tolerance, bile salt tolerance, autoaggregation capacity, antibacterial activity and antibiotic sensitivity. The encouraging results of the present investigation make this strain a reliable one for obtaining new probiotic preparations.

Acknowledgements: This work was carried out in Microbiology section of Dr Y.S. Parmar University of Horticulture and Forestry Nauni, Solan, H.P. India Authors wish to thank Dr. O.P. Ahlawat, Principal Scientist, Directorate of Mushroom Research, Chambaghat, Solan for his scientific advice and valuable suggestions.

\section{REFERENCES}

AHIRE, J.J., PATIL, K.P., CHAUDHARI, B.L., CHINCHOLKAR, S.B. 2011. A potential probiotic culture ST2 produces siderophore 2, 3dihydroxybenzoylserine under intestinal conditions. Food Chemistry, 127, 387 393. http://dx.doi.org/10.1016/j.foodchem.2010.12.126

ANEJA, K.R., 2003. Experiments in Microbiology, Plant pathology and Biotechnology, Biochemical activities of microorganisms, $4^{\text {th }}$ edn. New age International publishers, New Delhi, 245-275 pp.

Barefoot, S.F., Klaenhammer, T.R.1983.Detection and activity of Lactacin B, a bacteriocin produced by Lactobacillus acidophilus. Applied and Environment Microbiology, 45(6), 1808-1815.

BHAKTA, J.N., OHNISHI, K., MUNEKAGE, Y., IWASAKI, K. 2010. Isolation and probiotic characterization of Arsenic resistant lactic acid bacteria for uptaking Arsenic. International Journal of Chemical and Biological Engineering, 3, 4 .

COPPOLA, R., SUCCI, M., TREMONTE, P., REALE, A., SAlZANO, G., Sorrentino, E.2005. Antibiotic susceptibility of L. rhamnosus strains isolated from ParmigianoReggiano cheese. Lait, 193 204.http://dx.doi.org/10.1051/lait:2005007

DEL, Re. B., SGORBATI, B., MIGLIOLI, M., PALENZONA. 2000. Adhesion, autoaggregation and hydrophobicity of 13 strains of Bifidobacteriumlongum. Letters in Applied Microbiology, 31, 438-442.http://dx.doi.org/10.1046/j.13652672.2000.00845.x

FAO/WHO. 2002. Guidelines for the evaluation of probiotics in food: report of a Joint FAO/WHO Working Group on Drafting Guidelines for the Evaluation of Probiotics in Food.

FUKAO, M., OSHIMA, K., MORITA, H., TOH, H., KIM, S. W., SUZUKI, S., YAKABE,T., HATTORI, M., YAJIMA, N., 2013. Deep Sequencing of the 
Probiotic Lactobacillus brevis KB290 Harboring Nine Plasmids Reveals Genomic Stability. PLos one.8: e60521.http://dx.doi.org/10.1371/journal.pone.0060521.

GAUTAM, N., SHARMA, N., AHLAWAT, O.P.2014. Purification and characterization of bacteriocin produced by Lactobacillus brevis UN isolated from Dhulliachar -a traditional food product of North East India. Indian Journal of Microbiology.54(2), 185-189.http://dx.doi.org/10.1007/s12088-013-0427-7.

GAUTAM, N.,SHARMA, N.2009. Purification and characterization of purified bacteriocin of Lactobacillus brevisisolated from traditional fermented food of H.P. Indian Journal of Biochemistry and Biophysics 46, 337-341.

GOTCHEVA, V.E., HRISTOZOVA, T., HRISTOZOVA, M.G., ROSHKOVA,Z. 2002.Assessment of potential probiotic properties of lactic acid bacteria and yeast strains. Food Biotechnology,16, 211-225.http://dx.doi.org/10.1081/fbt120016668.

GREEN, A. 2010.The clinical use of probiotics. Protein health care. Ed Barlow J. Probiotics International Ltd, United Kingdom, 33-35 pp.

HALAMI, P.M., CHANDRASHEKAR, A., JOSEPH, R. 1999. Characterization of bacteriocinogenic strains of lactic acid bacteria in fowl and fish intestines and mushroom. Food Biotechnology, 13(2),121136.http://dx.doi.org/10.1080/08905439909549966.

HOQUE, M.Z., AKTER, F., HOSSAIN, K.M., REHMAN, M.S., BILLAH, M.M., ISLAM, K.M.M.2010. Isolation, identification and analysis of probiotic properties of Lactobacillus spp. From selective regional yoghurts. World Journal of Dairy and Food Sciences, 5(1), 39-46.

KANDLER,O.1983.Carbohydrate metabolism in lactic acid bacteria. Antonie Van Leeuwenhoek, 49,209-224. 24. http://dx.doi.org/10.1007/bf00399499.

KIERAN, A. RYAN, K. A., DALY, P., LI, Y., HOOTON, C., O'TOOLE, P.W.2008. Strain-specific inhibition of Helicobacter pylori by Lactobacillus salivarius and other Lactobacilli.Journal of Antimicrobial Chemotherapy,61(4),831-834.

KIMURA, H., SASHIHARA, T., MATSUSAKI, H., SONOMOTO, K., ISHIZAKI, A. 1998.Novel bacteriocin of Pediococcussp. ISK-1 isolated from well - aged bed of fermented rice bran. Annal New York Academic Science, 864 345-348.http://dx.doi.org/10.1111/j.1749-6632.1998.tb10336.x.

KLAYRAUNG, S., VIERNSTEIN, H., SIRITHUNYALUG, J., OKONOGI, S. 2008. Probiotic Properties of Lactobacilli Isolated from Thai Traditional Food. Science Pharmaceutical.76, 485-503.http://dx.doi.org/10.3797/scipharm.080611.

KOS, B., SUSKOVIC, J., VOKOVIC, S., SIMPRAGA, M., FRECE, J. MATOSIC, S.2003. Adhesion and aggregation ability of probiotic strain Lactobacillus acidophilus M92. Journal of Applied Microbiology, 94, 981987.http://dx.doi.org/10.1046/j.1365-2672.2003.01915.x.

LINDGREN, S.E., DOBROGOSZ. 1990. Antagonistic activities of lactic acid bacteria in food and feed fermentation. FEMS Micobiology Review, 87,149-163. http://dx.doi.org/10.1111/j.1574-6968.1990.tb04885.x

PELLETIER, C., BOULEY, C., CAYUELA, C., BOUTTIER, S., BOURLIOUX, P., BELLON-FONTAINE, M.N.1997. Cell surface characteristics of Lactobacillus casei subsp. casei, Lactobacillus paracasei subsp. paracasei, and Lactobacillus rhamnosus strains. Applied and Environmental Microbiology, 63, 1725-1731.

RANGANNA, S. 1997.Handbook of analysis and quality control for fruit and vegetable products. $2^{\text {nd }}$ edn. Tata McGraw Hill Publishing Comapany Ltd., New Delhi, India. $1109 \mathrm{p}$

SEKHON, B, S, JAIRATH, S. 2010. Prebiotics, probiotics and synbiotics: an overview. Journal of Pharmaceutical Education and Research,1(2), 13-36.

SHARMA, N., KAPOOR, G., GAUTAM, N.2009.Characterization of a partially purified bacteriocin of Bacillus spp. MTCC 43 isolated from Rhizosphere of radish (Raphanussativus)\& its application as a potential food biopreservative, Journal of Scientific and Industrial Research,68, 881-886.

TAMBEKAR, D.H., BHUTADA, S.A. 2010. An evaluation of probiotic potential of Lactobacillus sp. from milk of domestic animals and commercial available probiotic preparations in prevention of enteric bacterial infections. Recent Research in Science Technology, 2(10), 82-88.

WALKER, D.K., GILLILAND, S.E. 1993. Relationships among bile tolerance, bile salt deconjugation and assimilation of cholesterol by Lactobacillus acidophilus. Dairy Science, 7 (6), 956-961.http://dx.doi.org/10.3168/jds.s00220302(93)77422-6.

YAKABE, T., MOORE, E.L.S., YOKOTA, H., NOBUTA, S.M., FUKAO, P. H., YAJIMA, N.2009. Safety assessment of Lactobacillus brevis KB290 as a probiotic strain. Food and Chemical Toxicology. Journal homepage:www.elsevier.com/locate/foodchemtox.

ZHOU, J.S., PILLIDGE, C.J., GOPAL, P.K., GILL, H.S.2005.Antibiotic susceptibility profiles of new probiotic Lactobacillus and Bifidobacterium strains. International Journal of Food Microbiology, 98, 211217.http://dx.doi.org/10.1016/j.ijfoodmicro.2004.05.011. 